\title{
METHODICAL APPROACHES OF RESEARCH OF THE TEMPERATURE'S INFLUENCE ON COMPONENT COMPOSITION OF OVERVISCOUS OIL
}

\author{
• • уськов , • • яхов, • • йдуллин, • • Ш шкулов \\ I. A. Guskova, V. A. Sayakhov, L. K. Shaydullin, I. M. Ishkulov \\ льметьевский госуд рственный нефтяной институт, г. льметьевск
лючевые слов : сверхвзкк янефть; хром тогр фия; методик исследов ния; керн; скв жин ;
термическое воздействие; p створитель
Key words: over viscous oil; chromatography; research technique; core; well; thermal impact; solvent
}

фоне ухудшения структуры з п сов н блюд ется снижение среднего дебит добыв ющих скв жин по нефти, что ок зыв ет реш ющее влияние н экономические пок з тели р зр ботки нефтяных месторождений. ерспективным н пр влением является р зр ботк месторождений с трудноизвлек емыми з п с ми, к которым отнесены з лежи сверхвязкой нефти ( ) ) [1]. оссии основным способом добычи н месторождениях является п рогр вит ционное дрениров ние. последнее время н зрел необходимость р зр ботки и применения методов увеличения нефтеотд чи, обеспечив ющих более высокий потенци л вытеснения нефти, чем тр диционные тепловые методы.

ля проведения исследов ний по р зр ботке технологии добычи с использов нием р створителей был р зр бот н методик, котор я включ ет отбор керн, его н грев, воздействие р створителем и проведение хром тогр фического и микроскопического н лиз .

ром тогр фические исследов ния проводились н г зожидкостном хром тогр фе GC 2010 Plus, микроскопические исследов ния керн выполнялись с использов нием микроскоп Leica DM 750. сследов ния компонентного сост в проводились для лК нов от 10 до 40 (т блиц ).

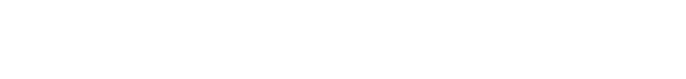

\begin{tabular}{|c|c|c|c|c|c|}
\hline \multirow[b]{2}{*}{ 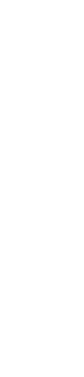 } & \multicolumn{5}{|c|}{ онцентр ция, \% } \\
\hline & 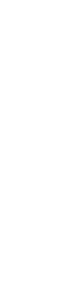 & 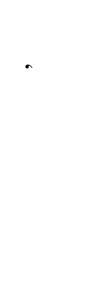 & 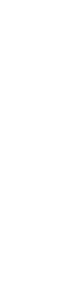 & 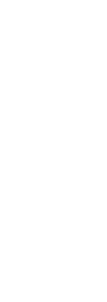 & 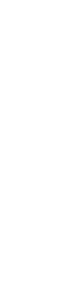 \\
\hline $10-19$ & 64,69 & 58,11 & 39,29 & 61,59 & 56,57 \\
\hline $20-29$ & 20,82 & 15,02 & 37,92 & 14,09 & 16,72 \\
\hline $30-40$ & 14,5 & 26,87 & 22,79 & 26,27 & 26,72 \\
\hline
\end{tabular}

езульт ты микроскопического и хром тогр фического н лизов контрольного обр зц керн предст вленын рисунк х 1,2.

к видно н рисунке 2, в контрольных проб х было отмечено м ксим льное содерж ние пент дек н ( ${ }_{15}$ с концентр цией $\left.14,74 \%\right)$, дек н ( ${ }_{10}$ с концентр цией $11,51 \%)$, фит н $\quad\left(\mathrm{C}_{20} \mathrm{H}_{42}\right.$ с концентр цией $\left.7,24 \%\right)$. целом концентр ция группы лк нов от 10 до 19 сост вил порядк $65 \%$ от общей концентр ции, концентр ция

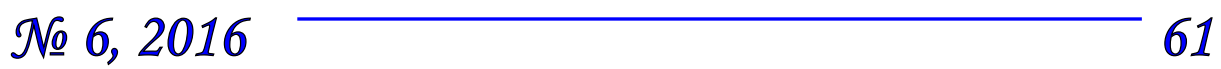


группы лк нов от 20 до $29-$ пр ктически $21 \%$, концентр ция группы лк нов от 30 до $40-$ порядк $14 \%$ от общей концентр ции.

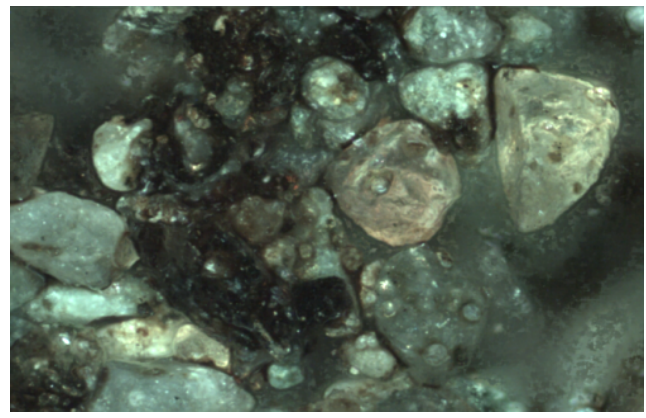

ис. 1. нимок контрольного обр зи керн

(увеличение $\mathrm{x} 5$ )

целом можно отметить, что в контрольном обр зце , основн я концентр ция приходится н группу лк нов от 10 до 19 . возр ст нием группы лк нов уменьш ется их доля в общей концентр ции. то говорит о том, что в контрольном обр зце

н блюд ется схожесть р спределения концентр ции по компонентному сост ву с нефтями средней вязкости.

ри проведении исследов ния н ми был смоделиров н ситу ция, когд под воздействием темпер туры отделяется жидк я ч сть от керн . промысловой пр ктике именно эт ч сть поступ ет н прием н сос . результ те проведения хром тогр фического н лиз, было уст новлено, что в сост ве , выделившейся под воздействием темпер туры средняя концентр ция группы лк нов от ${ }_{10}$ до ${ }_{19}$ p вн $58 \%$ от общей концентр ции, концентр ция группы лк нов от 20 до ${ }_{29}$ сост вил $15 \%$, концентр ция группы лк нов от 30 до $40-27 \%$ от общей концентр ции. ыло отмечено, что концентр ция группы лк нов от 10 до $\quad 19$ И 3 метно снизил сь, концентр ция группы лк нов от 30 до 40 возросл .

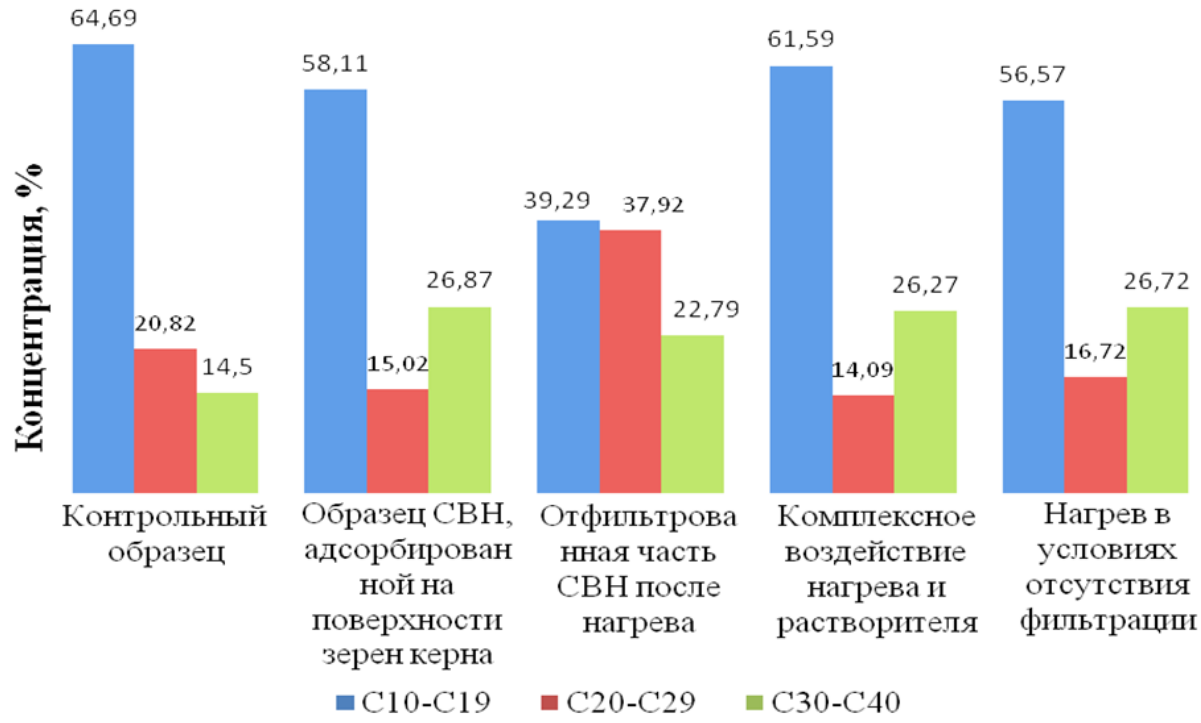

ис. 2. езульт ты исследов ний компонентного сост в

результ те проведения хром тогр фического н лиз было уст новлено, что в сост ве , выделившейся под воздействием темпер туры средняя концентр ция группы лк нов от 10 до ${ }_{19} \mathrm{p}$ вн $58 \%$ от общей концентр ции, концентр ция группы лк нов от 20 до ${ }_{29}$ сост вил $15 \%$, концентр ция группы лк нов от 30 до $40-$ 
$27 \%$ от общей концентр ции. ыло отмечено, что концентр ция группы лк нов от 10 до 19 И лк нов группы от 20 до 293 метно снизил сь, концентр ция группы лк нов от 30 до 40 возросл (см. рис. 2).

лее был проведен н лиз компонентного сост в ост точной , дсорбиров вшейся н поверхности зерен после н грев и отделения жидкой ч сти. ри н греве вязкость обр зц сниж ется, н чин ются внутримолекулярные процессы, под действием которых некотор я ч сть фр кций улетучив ется, ч сть стек ет, т кже ост ется н зерн х керн, тем с мым прид в я ему черный, темно-коричневый оттенок (рис. 3). ри этом средняя концентр ция группы лк нов от ${ }_{10}$ до ${ }_{19}$ сост вил $39 \%$, концентр ция группы лк нов от 20 до $29-38 \%$ и концентр ция группы лк нов от 30 до $\quad 40-23 \%$ от общей концентр ции (см. рис. 2).

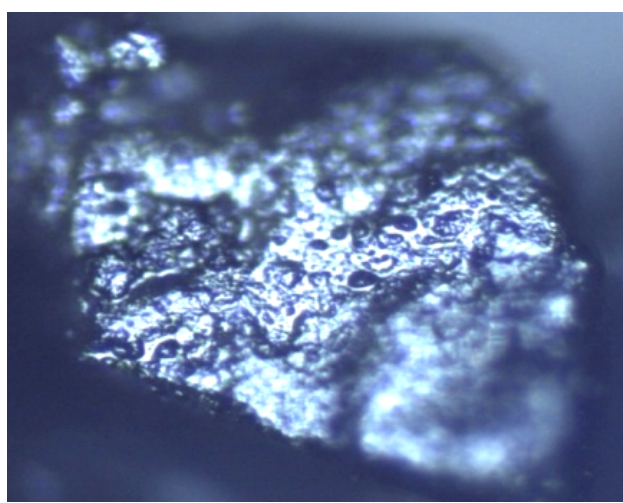

ис. 3. нимок обр зи керн подвергнутого термическому воздействию (увеличение х 10)

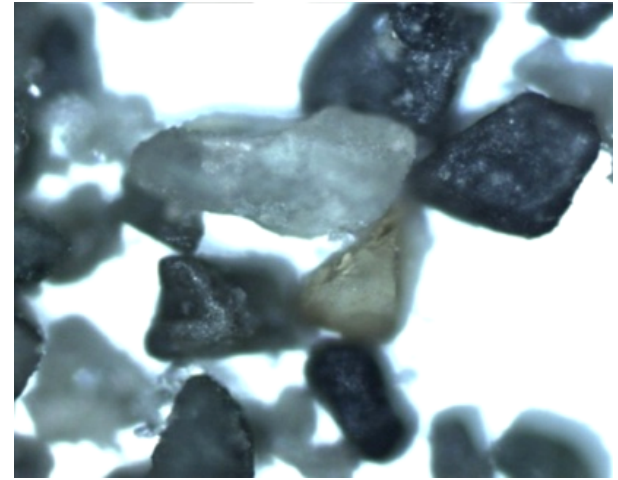

ис. 4. нимокобр зи керн подвергнутого комплексному воздействию р створителем и темпер турой (увеличение х 5)

ри проведении исследов ния т кже был смоделиров н ситу ция, когд н в процессе н грев происходит дополнительное воздействие р створителем. о микрофотогр фии керн (рис. 4) видно, что творителем с поверхности зерен керн .

редняя концентр ция группы лк нов от 10 до ${ }_{19}$ сост вил $62 \%$ от общей концентр ции, концентр ция группы лк нов от 20 до $29-14 \%$, концентр ция группы лк нов от 30 до $40-26 \%$ от общей концентр ции (см. рис. 2).

кже был выполнен хром тогр фический н лиз обр зц после термического воздействия в условиях отсутствия фильтр ции и компонентообмен . редняя концентр ция группы лк нов от ${ }_{10}$ до ${ }_{19} \mathrm{p}$ вн $57 \%$ от общей концентр ции, концентр ция группы лк нов от 20 до $29-$ сост вил $17 \%$, по группе лк нов от 30 до $40-$ $27 \%$ от общей концентр ции (см. рис. 2).

ким обр зом, по д нным т блицы и гистогр ммы (см. рис. 2) следует отметить, что нез висимо от вид н грев групп более тяжелых компонентов $30^{-} \quad 40$ в исследов нных обр зц х увеличив ется по ср внению с содерж нием в контрольном обр зце. осле н грев и охл ждения концентр ция группы углеводородов $10^{-} \quad 19$ изменил сь в $1,65 \mathrm{p} 3$, или н $25 \%$. сли технология предусм трив ет одновременное воздействие темпер туры и р створителя, то компонентный сост в выделившейся пр ктически не меняется по ср внению с контрольным обр зцом, что свидетельствует о перспективности р зр ботки технологий добычи , предусм трив ющих комплексное воздействие темпер туры и р створителя. ибольш я концентр ция по группе лк нов 20- 29 отмеч ется у обр зц , отфильтров нной после н грев и охл ждения, и сост вляет $38 \%$, увеличение по ср внению с контрольным обр зцом в 1,82 p 3 . 
то явление объясняется тем, что в процессе н грев сниж ется вязкость нефти, что способствует д льнейшей фильтр ции. ля обр зцов, н которые ок зыв лось термическое воздействие, х р ктерн небольш я концентр ция д нной группы лк нов. онцентр ция группы лк нов 30 - 40 р зличн для обр зцов, которые подверглись и не подверглись термическому воздействию. ля обр зц (без термического воздействия) доля от общей ч сти сост вляет $14 \%$, в обр зц х, которые были подвергнуты термическому воздействию - 23-27\%.

blводbl

- $\quad$ пок з но, что при тепловом воздействии происходит изменение компонентного сост в , н грев и последующее охл ждение пл ст приводит к увеличению доли тяжелых компонентов и снижению доли легких компонентов;

- предложен методик исследов ния, обеспечив ющ я возможность тестиров ния технологий н основе хром тогр фического и микроскопического н лиз и керн

- д нный метод может быть использов н для выявления оптим льного интерв л темпер тур, при которых достиг ется минимиз ция потерь легких фр кций;

- микроскопический н лиз керн после теплового воздействия пок з л, что н поверхности зерен керн сформиров лся плотный дсорбционный слой, в сост в которого входят группы углеводородов $13^{-} \quad 16, \quad 24, \quad 34^{-} \quad 36$;

- выбор технологии добычи может быть основ н н требов ниях к компонентному сост ву добыв емой нефти;

- если имеется цель добыв ть м ксим льно не преобр зов нную , то необходимо применять новые, более совершенные технологии, одной из которых может служить добыч с использов нием р створителей. основе выполненных исследов ний предл г ется продолжить изучение возможности применения р створителей для добычи ;

- для достижения м ксим льной компонентоотд чи предл г ется применять комплексные технологии, включ ющие тепловое воздействие и воздействие р створителем;

- если позволяют м тери льные и технические условия, то необходимо произвести испыт ния по комплексному воздействию р створителей н пл ст, возможно увеличение добычи з счет синергетического эффект ;

- необходимо выполнение исследов ний р створителей и поиск оптим льного интерв л темпер тур воздействия для конкретных геолого-физических условий;

- если же добыч осуществляется только с помощью теплового воздействия, то необходимо созд в ть и поддержив ть термически, т кже гидродин мически р вновесную систему, котор я не позволял бы исп ряться легким компонент м.

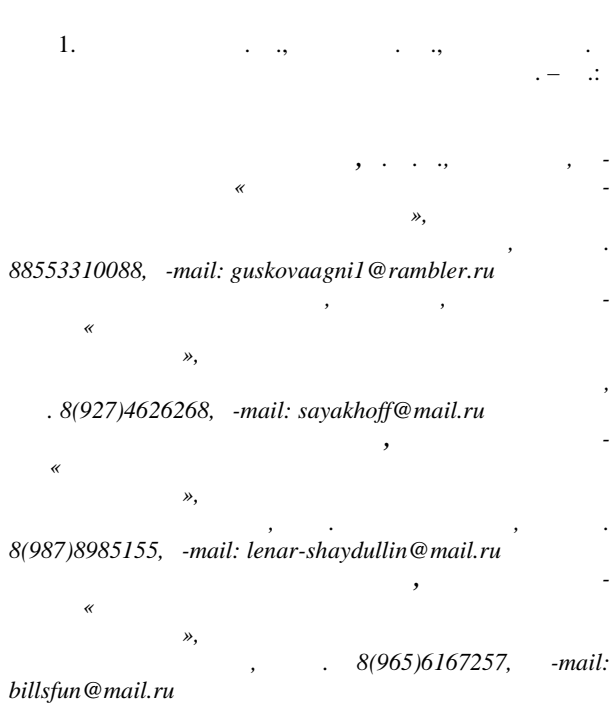

войств тяжелых нефтей и битумов пермских отложений , 2015. - $343 \mathrm{c}$.

Information about the authors

Guskova I. A. Doctor of Engineering Sciences, Professor, Head of Department "Development and exploitation of oil and gas fields". Almetyevsk State Oil Institute, Almetyevsk, tel.88553310088, e-mail: guskovaagni1@rambler.ru

Sayakhov V. A., Graduate student, Assistant of Department «Development and exploitation of oil and gas fields», Almetyevsk State Oil Institute, Almetyevsk, tel. 8(927)4626268,e-mail: sayakhoff@mail.ru

Shaydullin L. K., Master-student of Department «Development and exploitation of oil and gas fields», Almetyevsk State Oil Institute, Almetyevsk, tel. 8(987)8985155, e-mail lenar-shaydullin@mail.ru

Ishkulov I. M. Master-student of Department «Development and exploitation of oil and gas fields», Almetyevsk State Oil Institute, Almetyevsk, tel. 8(965)6167257, e-mail: billsfun@mail.ru 